\title{
Pharmaceutical care to pregnant women carrying human immunodeficiency virus
}

\author{
Geysa Aguiar Romeu ${ }^{1,2^{*}}$, Larissa Varela de Paiva1, Mariana Mota Moura Fé2 \\ ${ }^{1}$ Course of Pharmacy, Health Sciences Center, University of Fortaleza (UNIFOR), \\ ${ }^{2}$ District Hospital Gonzaga Mota Messejana (DHGMM)
}

\begin{abstract}
The purpose of this present study was to know the pharmacoepidemiological profile of pregnant women carrying HIV, the prevention actions against vertical transmission, and evaluate the service respecting the patients' level of satisfaction. It was developed a quali-quantitative longitudinal study, with the sample being composed by pregnant women carrying HIV attended at the Pharmaceutical Care Service of a public hospital of Fortaleza - state of Ceará, during the period between January and September, 2007. The data were collected by means of follow-up cards, patients' medical history and, finally, interviews to verify the users' level of satisfaction related to the service. Twenty seven pregnant and parturient women have participated in the study. The mean profile found was of a single woman, aged in the range between 18 and 28 years, of Caucasian race or dark colored, with familial revenue below the minimum wage, having elementary or high school, and being unemployed. It was observed that $77.8 \%(\mathrm{n}=21)$ of patients followed all prevention strategies against maternal-infant transmission. Twenty nine drug related problems have been detected, out of which $51.7 \%(n=15)$ were resolved. The general level of satisfaction respecting the Pharmaceutical Care Service was quite satisfactory. By means of the Pharmaceutical Care Service, the pharmacist professional effectively collaborates for the correct utilization of medications, and this action results directly in a decrease of HIV vertical transmission.
\end{abstract}

Uniterms: Pharmacoepidemiology. Pharmaceutical Care. HIV. Pregnant women/pharmacoepidemiological profile.

Objetivou-se com o presente estudo conhecer o perfil farmacoepidemiológico das gestantes portadoras do vírus HIV, as ações de prevenção da transmissão vertical e avaliar o serviço quanto ao nível de satisfação das pacientes. Realizou-se estudo quali-quantitativo, longitudinal, sendo a amostra composta pelas gestantes portadoras do vírus HIV atendidas no Serviço de Atenção Farmacêutica de um hospital público de Fortaleza-CE, no período de janeiro a setembro de 2007. Coletaram-se os dados por meio de fichas de seguimento, prontuários das pacientes e, finalmente, entrevistas para verificar o nível de satisfação das usuárias em relação ao serviço. Participaram do estudo 27 gestantes e parturientes infectadas pelo HIV. O perfil encontrado foi de mulheres solteiras, na faixa etária de 18 a 28 anos, de cor branca ou parda, com renda familiar inferior a um salário mínimo, com ensino fundamental ou médio e desempregadas. Observou-se que $77,8 \%(n=21)$ pacientes seguiram todas as estratégias de prevenção da transmissão materno-infantil. Detectaram-se 29 problemas relacionados ao uso de medicamentos, dos quais 51,7\% ( $n=15)$ foram resolvidos. O nível de satisfação geral em relação ao serviço de atenção farmacêutica foi bastante satisfatório. Por meio do serviço de atenção farmacêutica, o profissional farmacêutico colabora com a utilização correta dos medicamentos, podendo repercutir diretamente na redução da transmissão vertical do HIV.

Unitermos: Farmacoepidemiologia. Atenção Farmacêutica. HIV. Gestante/perfil farmacoepidemiológico.

*Correspondence: G. A. Romeu. Centro de Ciências da Saúde, Universidade de Fortaleza, Av. Washington Soares, 1321 - Bloco C - Edson Queiroz, 60811905 - Fortaleza - CE, Brazil. E-mail: geysa@unifor.br 


\section{INTRODUCTION}

It is called vertical transmission (VT) of the human immunodeficiency virus (HIV) the phenomenon of infant infection occurring during pregnancy, and at parturition or puerperium by means of breast-feeding. However, the newborn from a mother carrying HIV has the opportunity to do not self-infect. Currently, there are effective measures to avoid the risk of transmission, such as: the early diagnosis of infected pregnant women, the use of antiretroviral drugs (ARV), the programmed cesarean section, and the suspension of breast-feeding. During the prenatal phase, all pregnant women have the right and should consummate the test for HIV detection. As early is done the diagnosis, as better are the chances to avoid the transmission to the newborn (Brazil, 2006).

It is estimated that in Brazil, more than 17 thousand pregnant women infected by HIV give birth every year, however, only about seven thousand women receive prophylaxis with ARV at the moment of delivery (Falci, Bay, 2006). The maternal-infant transmission of HIV continues to be the main path of newborn infection, a fact that is responsible for more than $90 \%$ of reported cases of acquired immunodeficiency syndrome (AIDS) in this population (Castro et al., 2001; Falci, Bay, 2006; Sbalqueiro et al., 2004; Yoshimoto, Diniz, Vaz, 2005). Up to 2005 June, 370,499 cases of HIV infection/AIDS had been reported in Brazil, being 118,520 in women (31.9\%) (Romanelli et al., 2006). Due to this progressive growth in the number of AIDS cases between women, mainly in women at reproductive age, the VT is assuming great epidemiologic importance (Brito et al., 2006; Cavalcante et al., 2004; Lemos, Gurgel, Fabbro, 2005; Romanelli et al., 2006).

The evaluation of pregnant women respecting to immunosuppression and risk of vertical transmission is done through the determination of T-CD4 lymphocytes and viral load, with samples collected ideally before to start the use of ARV. This intervention is done during the pregnant women follow-up and after the stage of counseling. The gravid women should have available the development of these examinations, so that they could start as early as possible the prophylaxis with ARV. The treatment of pregnant women should be individualized, taking into account their examinations and their medicative past; it should be clarified to every patient if the strategy aims only the transmission prevention, or, otherwise, there are ARV criteria for treatment, requiring so its maintenance after delivery (Falci, Bay, 2006).

The main purpose of ARV therapy is to delay the immunodeficiency progression and/or restore the immunity as much as possible, increasing so the time and quality of life of infected person. However, the natural evolution of HIV infection is characterized by intense and continuous viral replication occurring within many cellular and anatomic compartments, which results, mainly, in the destruction and dysfunction of T-lymphocytes expressing the membrane antigen CD4 (T-CD4 lymphocytes) and other cells of the immune system. The progressive depletion of T-CD4 lymphocytes, together with other quantitative and qualitative alterations of the immune system, leads to immunodeficiency, which, in its more severe form, manifests itself by the appearance of opportunistic infections and neoplasias, which are AIDS characteristics. Therefore, the maximal suppression of viral replication is desirable, in order to decrease or reverse the immunologic damage (Brazil, 2006).

A great barrier for the implementation of ARV use in HIV infected pregnant women is the lack of a prenatal assistance. The moment of virus transmission from the mother to her fetus is crucial and it is necessary to intervene with ARV drugs during the prenatal assistance, at labor, as well as administering these drugs to the newborn. In Brazil, although ARV medications are available for all pregnant women population infected by HIV and their respective infants, the difficulties of public health network to provide laboratory diagnosis for this infection, and the insufficient coverage respecting the women tested during the prenatal phase, result in the administration of injectable zidovudine (AZT) in less than $50 \%$ of the deliveries of pregnant women who are, probably, infected by HIV (Brazil, 2006).

In a research developed in 1994, it was evidenced a significant decrease in the rate of VT, from $25.5 \%$ to $8.3 \%$, with the use of AZT in pregnant women and their newborn (Connor et al., 1994). Therefore, it is possible to assert that the correct use of ARV is of fundamental importance to decrease the rates of VT. In this setting, the Pharmaceutical Care (PC) appears as a practice focused on the patient, where the pharmacist is the professional that could effectively contribute for the adequate use of ARV, adopting for that, therapeutic strategies of easy understanding as well as establishing a friendly and confidential relationship with patients, in order to clarify all doubts that could occur respecting the use of medication (Lyra Júnior et al., 2004; Storpirtis, Ribeiro, Marcolongo, 2000).

Due to infection severity and taking into account the possibility of a VT decrease, it becomes important the access of pregnant women to a Service of Pharmaceutical Care, during the use of ARV in the prenatal phase (Sbalqueiro et al., 2004). In this type of specialized service, the pharmacist passes to follow-up better the patient, knowing not only the used medication, but also the way 
the patient uses it, beyond to obtain information about the patient's personal feelings respecting the treatment and respective health problem. In the practice, the pharmacist, in an organized way, collects and evaluates information respecting the patient, including the identification of possible problems related to the use of medicines, which are known as Drug Related Problems (DRP). Once identified a problem, the pharmacist looks for a solution, formulates and puts into practice a therapeutic plan to correct it. The Pharmaceutical Care is much diffused nowadays and represents a desired activity for many pharmacists (Cebrim/ CFF, 2006).

However, the orientation provided by the pharmacist aims not only at the prevention, detection of DRP, and resolution of negative results related to medicines (Medication Negative Results - MNR), but also the patients education respecting the use of medicines, the interaction between the pharmacist and other healthcare professionals, a pathologic follow-up of the patient in order to optimize the pharmacotherapy, and the effective participation of the professional in the community (Cebrim/CFF, 2006).

The inadequate AIDS pharmacotherapy, besides to constitute an important public health problem all over the world, with great social and economical consequences, brings the risk of transmission to the infant, in case of HIV infected pregnant women. The sensitization of these patients, respecting the importance of treatment adherence and adequate use of medicines, provides higher effectiveness and safety for their pharmacologic treatment.

The Pharmaceutical Care Service for pregnant patients carrying HIV was implanted in the District Hospital Gonzaga Mota Messejana (DHGMM), in 2007 January, having as a purpose to contribute to decrease the VT. The intention in this work, therefore, is to know the profile of patients attended in this service, their access to actions for VT prevention and control, as well as to evaluate the service by means of the satisfaction level of patients, in order to establish proposals for its improvement.

\section{MATERIAL AND METHODS}

This is a quali-quantitative longitudinal study developed in the period between January and September, 2007, in the District Hospital Gonzaga Mota Messejana (DHGMM), a secondary hospital localized in FortalezaCeará-Brazil, attending mainly women looking for services of gynecology and obstetrics, and having 84 beds. As an average, about six thousand women are attended monthly over there.

The Service of Specialized Attendance in Maternal-infant HIV/AIDS at DHGMM was started in 2005, endowed of infectology clinics for the pregnant women carrying HIV, and pediatric infectology service, besides prenatal follow-up, parturition and post-parturition attendance, psychosocial and nutritional assistance for the serum-positive pregnant women as well as for children in this same situation, which is extended up to their seroconversion or positive serology confirmation for HIV. It was the first clinical service in HIV offered by the city of Fortaleza, with the merit to be the second in the state of Ceará to attend children. It offers also the Pharmaceutical Care Service where the ARV medications are dispensed with the due orientations, assuring so the access of users to these drugs, which are regularly made available by the Ministry of Health. It is developed even the laboratory follow-up with the execution of CD4 and Viral Load examinations, which is occurring since the service registration as a requester unit, close to the Ministry of Health/National Program of STD/AIDS/Laboratory Unit (Secretaria Municipal de Fortaleza, 2007).

During the study period, 38 pregnant or parturient women carrying HIV have been registered in the Counseling Program of STD/AIDS. Those who participated in the Pharmaceutical Care Service have been included, being excluded those who had less than three pharmaceutical consultations, and those who did not agree in participate of this research.

The study was divided into two steps. In the first one, pharmacoepidemiological data were collected by means of pharmacotherapeutic follow-up cards and patients' medical history, being observed the following variables: personal information, obstetrical history, contamination path, moment of serology identification, execution of prenatal evaluation and number of consultations, access to prophylactic measures against vertical transmission, data respecting the pharmacotherapy, and description and classification of problems related to use of medications, or Drug Related Problems (DRP). It was adopted the DRP classification according to the Second Consensus of Granada (Comité de Consenso, 2002):

\section{Necessity:}

DRP 1 - the patient presents a health problem due to nonutilization of a necessary medication;

DRP 2 - the patient presents a health problem due to utilization of an unnecessary medication;

\section{Effectiveness:}

DRP 3 - the patient suffers a health problem as a consequence of a non-quantitative ineffectiveness of medication; 
DRP 4 - the patient suffers a health problem as a consequence of a quantitative ineffectiveness of medication;

\section{Safety:}

DRP 5 - the patient suffers a health problem as a consequence of a non-quantitative unsafety of medication;

DRP 6 - the patient suffers a health problem as a consequence of a quantitative unsafety of medication.

The second step was composed by an interview to verify the grade of comprehension of the orientations about the use of ARV, and the satisfaction level of users respecting the Pharmaceutical Care Service. It was utilized a questionnaire pre-validated by Lyra Júnior et al. (2004), composed by four dimensions: quality of orientation; pharmacist consideration respecting to patients; professional competence, and pharmacotherapy management. The questionnaire is formed by 14 questions, every one with a scale composed by five alternatives (always, almost always, sometimes, almost never, never). The application of this instrument was developed individually, in a privative place, only with patients who authorized the interview, after signing an informed consent form.

The data were analyzed using the software Epi-Info version 3.4.1 and the results were organized in the form of tables. The study has followed the ethical precepts for research involving human beings, according to Resolution \# 196/96 of National Health Council, being approved by the Institutional Review Board/Independent Ethics Committee of the University of Fortaleza.

\section{RESULTS}

From January to September, 2007, 38 patients were registered in the program STD/AIDS of DHGMM, out of which $71.0 \%(n=27)$ were attended at the Pharmaceutical Care Service, and all of them were included in the $1^{\text {st }}$ phase of the research. Out of these patients, $55.5 \%(n=15)$ answered the service questionnaire of evaluation ( $2^{\text {nd }}$ phase). Table I describes their demographic characteristics. The mean profile of patients carrying HIV attended at DHGMM is of a single woman, aged in the range between 18 and 28 years, of Caucasian race or dark colored, with familial revenue below the minimum wage, having elementary or high school, and being unemployed.

Respecting to habits, it was verified that $81.5 \%$ $(\mathrm{n}=22)$ of the interviewed women did not smoke and $88.9 \%(n=24)$ did not consume teas frequently. No one had the habit of drink coffee and practice physical exercises, only $3.7 \%$ used to ingest alcoholic beverages, while the remaining ones did not present this habit.

When started the pharmacotherapeutic follow-up, $85.2 \%(n=23)$ of patients were pregnant and $14.8 \%(n=4)$ parturient, being that $37.0 \%(n=10)$ reported that their pregnancy was not planned, nevertheless they accepted to be submitted to prenatal evaluation, and utilized the ARV drugs with prophylactic purpose. Out of the patients knowing their seropositivity before the pregnancy (37.0\%; $\mathrm{n}=10$ ), three stated that the pregnancy was planned. The remaining ones $(63.0 \%$; $n=17)$ discovered to be seropositive on occasion of the anti-HIV test, done at prenatal evaluation. The majority of patients (63.0\%) started the prophylaxis with ARV at the third quarter of pregnancy. Respecting to contamination path, the information was available for $59.2 \%(n=16)$ of cases and, out of these patients, $87.5 \%(n=14)$ were infected by means of sexual contact with the respective mate (51.9\% of total) (Table II).

Satisfactory results were obtained respecting to prevention strategies against vertical transmission, being observed that $92.6 \%(\mathrm{n}=25)$ patients have done the antiHIV test in the prenatal evaluation and $88.9 \%(n=24)$ utilized ARV during the prenatal phase. Injectable AZT was administered during the cesarean operation of $85.2 \%$ $(n=23)$ pregnant women, and all of them have suspended the breast-feeding. Respecting to use of oral AZT by the newborn, only one has taken it in the first 24 hours, and all of them utilized the medication during their first six weeks of life. All the prevention strategies were followed by $77.8 \%(n=21)$ of patients (Table III).

Table IV demonstrates that, out of the patients that used ARV in the prenatal phase $(88.9 \%$; $=24), 87.5 \%$ $(\mathrm{n}=21)$ received a first-choice therapy, according to recommendations from the Ministry of Health (Brazil, 2006). A proportion of $95.8 \%$ presented high level of treatment adherence. Respecting to duration time of prophylaxis, the majority utilized ARV during 1 to 3 months, confirming the treatment beginning from the third quarter of pregnancy.

Twenty nine problems related to use of medications, or Drug Related Problems (DRP), were detected, resulting in an average of 1.1 DRP per patient, with variation of 0 to 8 . The categories of necessity, effectiveness, and safety have presented, respectively, in 14, 4 and 11 cases, being detected the DRPs 1, 4 and 5 as the more prevalent ones (Table V). The main adverse reactions related DRPs (DRP 5) were nauseas and vomits (7.4\%), anemia $(7.4 \%)$, diarrhea $(11.1 \%)$, cutaneous rash, dizziness, headache and cloudy vision (3.7\% each). Respecting to accomplishment of pharmacological treatment, cases of forgetfulness $(7.4 \%)$, utilization of wrong quantity of medication (14.8\%), treatment suspension for one's 
TABLE I - Distribution of patients carrying human immunodeficiency virus (HIV), according to age range, civil status, race, familial revenue, scholarship, and profession $(n=27)$ (DH)

\begin{tabular}{|c|c|c|}
\hline Variables & $\mathrm{N}$ & $\%$ \\
\hline \multicolumn{3}{|l|}{ Age range } \\
\hline 18 to 28 & 15 & 55.6 \\
\hline 29 to 39 & 12 & 44.4 \\
\hline \multicolumn{3}{|l|}{ Civil status } \\
\hline Single & 10 & 37.1 \\
\hline Married & 5 & 18.5 \\
\hline Separate & 5 & 18.5 \\
\hline Stable union & 5 & 18.5 \\
\hline Not informed & 2 & 7.4 \\
\hline \multicolumn{3}{|l|}{ Race } \\
\hline Caucasian & 9 & 33.3 \\
\hline Dark & 9 & 33.3 \\
\hline Black & 5 & 18.5 \\
\hline Not informed & 4 & 14.8 \\
\hline \multicolumn{3}{|l|}{ Familial revenue } \\
\hline$<1$ minimum wage & 9 & 33.3 \\
\hline 1-2 minimum wages & 6 & 22.2 \\
\hline 2-3 minimum wages & 1 & 3.7 \\
\hline Not informed & 11 & 40.7 \\
\hline \multicolumn{3}{|l|}{ Scholarship } \\
\hline Illiterate & 4 & 14.8 \\
\hline Elementary school & 11 & 40.7 \\
\hline High school & 11 & 40.7 \\
\hline Not informed & 1 & 3.7 \\
\hline \multicolumn{3}{|l|}{ Profession } \\
\hline Housewife & 10 & 37.1 \\
\hline Seamstress & 2 & 7.4 \\
\hline Charwoman & 2 & 7.4 \\
\hline Other & 4 & 14.8 \\
\hline Not informed & 9 & 33.3 \\
\hline
\end{tabular}

own hand (3.7\%) due to occurrence of adverse reaction, and treatment desertion (3.7\%) due to non-acceptance of seropositive condition were verified. Nineteen pharmaceutical intervention were developed and $51.7 \%(n=15)$ of problems were resolved.

The questionnaire utilized in the present study has evaluated the quality of orientations, the pharmacist consideration respecting to patients, the professional competence, and the pharmacotherapy management, as well
TABLE II - Distribution of patients carrying human immunodeficiency virus (HIV) according to obstetric history, contamination path, serology identification, prenatal evaluation execution, and the number of prenatal consultations $(n=27)$ (DHGMM, 2007)

\begin{tabular}{lcc}
\hline Variables & $\mathrm{n}^{\mathrm{o}}$ & $\%$ \\
\hline Obstetric situation & & \\
Pregnant woman & 23 & 85.2 \\
Parturient & 4 & 14.8 \\
Planned pregnancy & & \\
Yes & 6 & 22.2 \\
No & 10 & 37.0 \\
Not informed & 11 & 41.0 \\
Gestational age & & \\
2nd quarter & 4 & 14.8 \\
3rd quarter & 17 & 63.0 \\
Not informed & 6 & 22.2 \\
Contamination path & & \\
Sexual (mate) & 14 & 51.9 \\
Sexual violence & 2 & 7.4 \\
Not informed & 11 & 40.7 \\
Serology identification & & \\
Prenatal & 17 & 63.0 \\
Before pregnancy & 10 & 37.0 \\
Prenatal evaluation & & \\
Yes & 25 & 92.6 \\
No & 2 & 7.4 \\
Number of prenatal consultations & \\
1 to 4 & 10 & 57.0 \\
5 to 8 & 15 & \\
Not informed & 2 & \\
\hline & & \\
\hline
\end{tabular}

as the patients' general satisfaction with the service. The satisfaction with both, the pharmacist and the program, has presented very adequate results, as demonstrated at Table VI. All interviewed women have considered that the pharmacist had always oriented respecting the adequate use of medications (questions 3, 4, and 6). The doubts were always clarified, and the pharmacist had been always available for the necessary orientations (questions 7, 8, and 12). No patient has felt difficulty to understand the pharmacist (question 11). Respecting to the time available for PC sessions, the sessions lasted an average of 30 minutes, and it was enough to receive the adequate information (questions 1 and 7). Respecting the professional competence and pharmacotherapy management, it was 
TABLE III - Distribution of patients carrying human immunodeficiency virus (HIV) according to access to prevention strategies against vertical transmission ( $\mathrm{n}=27)(\mathrm{DHGMM}, 2007)$

\begin{tabular}{|c|c|c|}
\hline Variables & $\mathrm{N}$ & $\%$ \\
\hline \multicolumn{3}{|c|}{ Realization of anti-HIV test in the prenatal phase } \\
\hline Yes & 25 & 92.6 \\
\hline No & 2 & 7.4 \\
\hline \multicolumn{3}{|c|}{ Use of ARV in the prenatal phase } \\
\hline Yes & 24 & 88.9 \\
\hline No & 3 & 11.1 \\
\hline \multicolumn{3}{|c|}{ Use of Injectable AZT at delivery } \\
\hline Yes & 23 & 85.2 \\
\hline No & 4 & 14.8 \\
\hline \multicolumn{3}{|l|}{ Type of delivery } \\
\hline Cesarean & 23 & 85.2 \\
\hline Vaginal & 4 & 14.8 \\
\hline \multicolumn{3}{|c|}{ Use of oral AZT by the newborn } \\
\hline First 24hours & 26 & 96.3 \\
\hline During the first 6 weeks & 27 & 100 \\
\hline \multicolumn{3}{|c|}{ Suspension of breast-feeding } \\
\hline Yes & 27 & 100 \\
\hline Todas as etapas & 21 & 77,8 \\
\hline
\end{tabular}

ARV: Antiretroviral; AZT: Zidovudine.

TABLE IV - Distribution of patients carrying human immunodeficiency virus (HIV) according to use of first-choice antiretroviral (ARV) therapy, treatment adherence, and time of prophylaxis $(\mathrm{n}=24)(\mathrm{DHGMM}, 2007)$

\begin{tabular}{lll}
\hline Variables & $\mathrm{N}$ & $\%$ \\
\hline
\end{tabular}

\section{First-choice ARV therapy}

$\begin{array}{lll}\text { Yes } & 21 & 87.5 \\ \text { No } & 3 & 12.5\end{array}$

Treatment adherence

\begin{tabular}{lcl} 
Yes & 23 & 95.8 \\
No & 1 & 4.2 \\
\multicolumn{2}{l}{ Time of prophylaxis (months) } & \\
$<1$ & 2 & 8.3 \\
1 to 3 & 18 & 75.0 \\
$>4$ & 4 & 16.7 \\
\hline
\end{tabular}

observed that $93.3 \%$ of patients affirmed that the pharmacist explained about the possible side effects caused by the new medication (question 2), and no patient reported that the pharmacist's explanations were not as detailed as they
TABLE V - Classification of problems related to use of medications, or Drug Related Problems (DRP), identified according to Second Consensus of Granada ( $\mathrm{n}=29)$ (DHGMM, 2007)

\begin{tabular}{lcc}
\hline DRP category & $\mathrm{n}^{\text {o }}$ & $\%$ \\
\hline Necessity & 14 & 48.3 \\
DRP 1 & 13 & 92.8 \\
DRP 2 & 1 & 7.1 \\
Effectiveness & 4 & 13.8 \\
DRP 3 & 1 & 25.0 \\
DRP 4 & 3 & 75.0 \\
Safety & 11 & 37.9 \\
DRP 5 & 8 & 72.7 \\
DRP 6 & 3 & 27.3 \\
Total & 29 & 100 \\
\hline
\end{tabular}

should be (question 5). The presence of dispersing factors in the PC room was mentioned by $14.3 \%$ of interviewed women (question 13). All of the attended women were satisfied with the service attendance (question 14).

\section{DISCUSSION}

The HIV epidemic is progressively advancing over the female population as a result of the increased heterosexual transmission, bringing negative effects for this population, as well as the possibility of HIV vertical transmission, a twofold malefic event (Lemos, Gurgel, Fabbro, 2005). Epidemiologic data have shown that, in Brazil, the majority of AIDS cases in women occur in the lower scholarship stratum and between those with less qualified occupation. Correspondingly to this situation, a growing impoverishment of the population assaulted by HIV occurs as well (Moura, Praça, 2006). The studied sample has provided results that are similar to those of the literature (Castro et al., 2001; Sbalqueiro et al, 2004), where the mothers are young, in the reproductive phase, possess lower scholarship and familial revenue, with the majority being housewives and do not living a stable union. These findings correspond also to country official data respecting the involvement of women with lower scholarship and revenue in the AIDS epidemic (Moura, Praça, 2006).

During pregnancy, HIV infection brings many consequences, of physical and emotional nature, for both, the pregnant woman and respective conception. For many times, the diagnosis is done during the prenatal phase, and could result in non-acceptance of serological findings by the patient, who could further deny to be submitted to any treatment or follow-up by healthcare professionals. 
TABLE VI - Level of satisfaction of patients carrying human immunodeficiency virus (HIV) respecting the attendance provided by the pharmacist and respecting the Pharmaceutical Care program ( $\mathrm{n}=15)(\mathrm{DHGMM}, 2007)$

\begin{tabular}{lc}
\hline Evaluated items & $\%$ \\
\hline 1. Does the pharmacist spend with you as much time as necessary? & 100 \\
2. Does the pharmacist explain about the possible side effects caused by the new medication to you? & 93.3 \\
3. If you have some doubt respecting prescription, is there a pharmacist always available to give orientation to you? & 100 \\
4. Does the pharmacist give you explanations, in a way that you understand? & 100 \\
5. Are not the pharmacist explanations as detailed as they should be? & 0 \\
6. Does the pharmacist confirm if you have understood how to take the medications? & 100 \\
7. Does not the pharmacist, sometimes, spend enough time with you? & 0 \\
8. Is the pharmacist friendly with you? & 100 \\
9. Is the pharmacist a competent professional? & 100 \\
10. Do you need to wait for a long time before attendance by the pharmacist? & 0 \\
11. Have you some difficulty to understand the pharmacist? & 0 \\
12. Is the pharmacist sincerely interested in your personal case? & 100 \\
13. Are there (in the PC room) many dispersing factors harming your attention during the session? & 14.3 \\
14. Are you satisfied with the attendance received from the pharmacist? & 100 \\
\hline
\end{tabular}

On the other hand, the opportunity for women to develop the HIV test in the prenatal phase assures their access to all steps of VT prevention. The great problem is the delay to obtain this examination result, which leads many of these women to start prophylaxis with ARV only at the third quarter of pregnancy. The work developed by Pluciennik (2003) has evidenced that the cost with serological tracking of pregnant women represents about $80 \%$ of the total costs for prevention of maternal-infant transmission, and that an important part of these costs is due to losses and unnecessary repetitions of tests. The late starting of prenatal follow-up represents also a barrier for the prevention of vertical transmission.

Castro et al. (2001) have described the study of 29 cases of pregnancy between women infected by HIV-1 virus. The main path of transmission was also sexual (41.4\%) and the majority has obtained the infection diagnosis before the child birth (72.3\%); however, the percentage of pregnant women that received prophylactic doses of ARV during pregnancy, in order to prevent VT, was lower $(65.5 \%)$ than the one found in this present study $(88.9 \%)$.

Another worrying fact was that the majority of patients have started the prophylaxis only at third quarter of pregnancy, contradicting the professed by the Ministry of Health, that is, prophylaxis with ARV should be started from the $14^{\text {th }}$ week of pregnancy forth. Nevertheless, the Ministry of Health itself affirms that "when the opportunity of ARV use at pregnancy beginning is lost, this therapy should be started at any gestational age, and the intravenous AZT should be settled at the moment of delivery". One of the purposes of ARV prophylaxis is to enable pregnant woman to reach delivery moment with the lower viral load as possible, preferably undetectable or, at least, lower than 1,000 viral copies per $\mathrm{mL}$ of serum (Brazil, 2006).

Out of the patients knowing their seropositivity before pregnancy, three stated that pregnancy was desired, reporting that they wanted to generate a child and become mother, even being HIV bearer. The women that already knew their serologic status before pregnancy, had many more chances to receive all prevention phases, than those who knew their status only during pregnancy (Cavalcante et al, 2004); and considering that a planned pregnancy could decrease the risk for VT, in the extent that the levels of viral load and T-CD4 lymphocytes are effectively controlled, it is assumed that such situation is more favorable than a non-planned pregnancy (Silva, Alvarenga, Ayres, 2006).

On the other hand, it was evidenced the non-use at all, or the inadequate use of contraceptives and preservatives, in the report of patients who knew their infected status and alleged undesired pregnancy. A study respecting the contraceptive behavior of 184 women bearing AIDS in Santo André - state of São Paulo has verified 51 (27.8\%) undesired pregnancies, which were also related to masculine preservative failures or non-use at all of contraceptive methods (Figueiredo, 2001)

A research mentioned by Castro et al. (2001) reveals that less than $50 \%$ of the patients who discover their HIV 
infection, effectively, decide to interrupt their pregnancy; and many of them become pregnant again. Another work, developed in Belo Horizonte - state of Minas Gerais, has shown that despite the majority of patients $(67.6 \%)$ have presented only one pregnancy after knowing their infected status, patients with two to seven pregnancies after diagnosis have also been identified (Romanelli et al., 2006).

The two patients who were not submitted to prenatal examination received urgency care due to occurrence of home parturition. It is known that the majority of cases of VT of HIV occur during the labor and parturition $(60 \%$ to $65 \%$ ), and the remaining cases (35\% to $40 \%)$ in the intrauterine period, mainly in the last weeks of pregnancy (Brazil, 2006). Therefore, the women who have their diagnosis at delivery moment or after it, loose all opportunities for development of prophylaxis (Cavalcante et al, 2004). The type of delivery has been largely discussed as a risk factor, being the elective cesarean operation associated to a lower risk for VT than the vaginal delivery (Brazil, 2006; Yoshimoto, Diniz, Vaz, 2005).

Breast-feeding represents an additional risk for transmission of 7 to $22 \%$. This risk increases, being of approximately $30 \%$, when the mother infection occurs during the nursing period. Because of that, mothers are advised to suspend the breast-feeding (Brazil, 2006). However, Ortigão (1995) discusses that mother's milk could be the single nutritional source for the nursling in low revenue families, making that the risk to take HIV becomes less relevant than the risk of death due to innutrition. This author quotes that the World Health Organization (WHO) recommends that in countries where infectious diseases and innutrition are the main causes for child mortality, the breast-feeding should be recommended for all mothers, including the ones with HIV infection. In Brazil, particular cases should be evaluated for the adoption of conducts addressed to every region and social situation. Always as possible, the breast-feeding is counter-indicated and all efforts should be summed in order to provide adequate artificial feeding. All the patients attended at the service of Pharmaceutical Care develop this phase for prevention, passing the newborns to receive a lacteous formula offered by DHGMM.

Respecting the use of prophylactic antiretroviral (ARV), a study developed by Connor (1994) has demonstrated a significant fall in the VT rate, from $25.5 \%$ to $8.3 \%$, with the use of AZT in the pregnant woman and the newborn. When all of the recommendations are followed, the VT rates achieve 1 to 2\% (Brazil, 2006; Romanelli et $a l, 2006)$. This specific information is provided to patients during the exercise of Pharmaceutical Care, and increases, in such a way, the mother confidence and hope respecting the seronegativity of the newborn. The children of the 21 patients who developed all the prevention phases, effectively, have great chances to be free of virus contamination; however, the data referring to serological condition of these children are not available yet. Results obtained through the study of trend to VT after the settlement of ARV therapy in Brazil, beginning in 1996, have consistently revealed the occurrence of a progressive decrease in the expected cases of AIDS due to VT, for children born from 1997 forth (Brito, et al., 2006).

When the intervention with zidovudine is developed belatedly in the pregnancy, and even only in the newborn, it is confirmed its efficacy in the decrease of VT (Brazil, 2006). In this study, all the newborns utilized AZT syrup during the first six weeks of life, increasing the possibilities for serological negativation.

During the Pharmaceutical Care, some problems related to use of medications, the so called Drug Related Problems (DRP), were detected; with the main ones being related to inadequate form of medication administration and appearance of adverse reactions, causing other health problems and, in some cases, harming the treatment adherence. The data found were similar to those from other works (Lignani Júnior, Greco, Carneiro, 2001; Menezes de Pádua et al., 2006), in which adverse reactions appearance was detected, such as: nauseas, vomits, diarrhea, allergies, anemia, abdominal pains, fatigue, headache, insomnia, pruritus, exanthema, among others.

The most frequently found DRP by Cerdá and Almiñana (2004), in a program of Pharmaceutical Care for patients with HIV infection, are related to adherence (30\%), adverse events (27\%), overdose (13\%), and sub-dose (9\%). The proportions of adverse reactions and overdose of these authors research were similar to those found in this present study, but the level of adherence was lower and the occurrence of sub-dose was higher. The exercise of Pharmaceutical Care determines that, from the DRP identification forth, it is necessary to produce a specific procedure addressed to obtaining the better and more concrete results as possible, for the patient. It contemplates also the education and prevention in the ambit of public health and, consequently, the information respecting recommendations addressed to help the rational use of medications.

The treatment adherence is referred to patient's conduct to follow the medical prescription respecting to posology, quantity of drugs, time of treatment and special recommendations for given medications. The treatment adherence is of fundamental importance in the case of acquired immunodeficiency syndrome, because incorrect drugs use is directly related to therapeutic failure and the appearance of HIV strains that are resistant to available medications (Lignani Júnior, Greco, Carneiro, 2001) 
In studies mentioned by Lignani Júnior, Greco e Carneiro (2001) the rate of adherence to ARV varies between $40 \%$ and $80 \%$. In another work developed in São Paulo and mentioned by the same authors, it was found an adherence rate of $73.8 \%$. In this study, the adherence rate was of $95.8 \%$, similar to that one found in the evaluation of a Pharmaceutical Care program addressed to improve the ARV treatment adherence in Spanish hospitals (94.8\%). It is so suggested that the existence of a Pharmaceutical Care Service could improve the ARV treatment adherence, and it has been observed that patients maintaining an adherence higher than $95 \%$ often present also a good virologic evolution (Jané et al., 2004).

The pharmaceutical interventions were effective, favoring the decrease of symptoms caused by inadequate pharmacotherapy, and increasing the patients' quality of life. The interventions consisted of orientation respecting the seropositive condition for HIV and the possibility of maternal-infant transmission, the importance of treatment adherence to avoid such transmission, the motivation to active participation in the proposed pharmacotherapy, the recognition of main adverse reactions, besides interventions close to the responsible infectologist for pharmacotherapy alterations.

The satisfaction study has presented high scores for all approached domains, which has provided results that are similar to those found by Lyra Júnior et al. (2004), except for the dispersing factors existing in the room utilized for the Pharmaceutical Care sessions. The non-existence of an appropriate consultation room for the practice of Pharmaceutical Care could embarrass the good progression of the proposed activities.

There is also the patients' satisfaction respecting the service of Pharmaceutical Care as an important result reflecting the grade of involvement of the pharmacist, during the humanized clinical care, as well as the shortages and expectations from patients during the received attendances. The evaluation of patients' satisfaction is an important measurement to assess the basic health attendance and, more specifically in this work, it is recognized as a quality indicator of pharmaceutical services (Lyra Júnior et al 2004; Armando, Uema, Sola, 2005).

It is considered that satisfied patients will continue to use the healthcare services, maintain specific links with the healthcare professionals, and accomplish the therapeutic regimens, obtaining so, the desired results of pharmacologic treatment (Armando, Uema, Sola, 2005). In this present study, it has been evidenced the high level of satisfaction from patients carrying HIV, justifying so the existence and continuity of Pharmaceutical Care Service at DHGMM.

\section{CONCLUSION}

Thanks to the detected number of Drug Related Problems, their respective resolution, and the great satisfaction of users respecting the service, it is possible to conclude that the pharmacist, when putting into practice the Pharmaceutical Care, becomes a fundamental tool for the prevention and resolution of Drug Related Problems, which could result directly in a decrease of HIV vertical transmission. However, complementary studies including a controlgroup, besides the children follow-up for definition of their serologic status are necessary for, definitely, determine the effective contribution of Pharmaceutical Care exercise for the decrease of HIV vertical transmission.

\section{ACKNOWLEDGMENT}

We thank to the board of directors of DHGMM for their authorization to develop this research and, particularly, to all patients who accepted to participate. We thank also to Jayson Viana Aguiar and the pharmacist Anna Cristina Matos Rolim for their text and abstract revision.

\section{REFERENCES}

ARMANDO, P., UEMA S., SOLÁ N. Valoración de la satisfacción de los pacientes con el seguimiento farmacoterapéutico. Seguim. Farmacoter., v.3, n.4, p.205-212, 2005.

BRASIL. Ministério da Saúde. Secretaria de Vigilância em Saúde. Programa Nacional de DST e AIDS. Recomendação para profilaxia da transmissão vertical do HIV e terapia anti-retroviral em gestantes. Brasília, 2006. 176 p.

BRITO, A.M., SOUSA, J.L., LUNA, C.F., DOURADO, I. Tendência da transmissão vertical de AIDS após terapia anti-retroviral no Brasil. Rev. Saúde Públ., v.40, suppl., p.18-22, 2006.

CASTRO, T.P.T., DE LORENZI, D.R.S., TONIN, C.,ZAPPAROLI, M. HIV e gestação. Rev. Cient. AMECS., v.10, n.1, p.1-8, 2001

CAVALCANTE, M.S., RAMOS JÚNIOR A.N., SILVA T.M.J., PONTES L.R.S.K. Transmissão vertical do HIV em Fortaleza: revelando a situação epidemiológica em uma capital do nordeste. Rev. Bras. Ginecol. Obstet., Rio de Janeiro, v.26, n.2, p.131-138, 2004.

CEBRIM/CFF. Elementos para apoiar a prática farmacêutica na farmácia comunitária. Rev. Farmacoter., v.11, n.3, p.59-60, 2006. 
CERDÁ, J.M.V., ALMIÑANA, M.A. Programa de atención farmacéutica a pacientes VIH con tratamiento antirretroviral: metodología y documentación. Farm. Hosp., v.28, n.1, p.7279, 2004.

COMITÉ DE CONSENSO. Segundo Consenso de Granada sobre problemas relacionados con medicamentos. Ars Pharm., v.43, n.3-4, p.175-184, 2002.

CONNOR, E.M., SPERLING, R.S., GELBER, R., KISELEV, P., SCOTT, G., SULLIVAN, M.J. Reduction of maternalinfant transmission of human immunodeficiency virus type I with zidovudine treatment. N. Engl. J. Med., v.331, n.18, p.1173-1180, 1994.

FALCI, D.R., BAY, M.B. Terapia Anti-Retrovial. In: PASQUALOTTO, A.C., SCHWARZBOLD, A.V. Doenças Infecciosas: consulta rápida. Porto Alegre: Artmed, 2006. p.405-448.

FIGUEIREDO, R. Comportamento contraceptivo de mulheres com AIDS da cidade de Santo André - SP. Brasília, 2001. Available at: <http://www.usp.br/nepaids/ce-sa.pdf $>$. Accessed on: 30 jun. 2008.

JANÉ, C.C., CREUS, M.T., BARRUETA, O.I., SÁNCHEZ, O.D., ECHEVARRÍA, O.M., DÍAZ, B.G. Evaluación de un programa de atención farmacéutica dirigido a mejorar la adherencia al tratamiento antirretroviral. Farm. Hosp., v.28, n.1, p.19-26, 2004.

LEMOS, L.M.D., GURGEL, R.Q., FABBRO, A.L.D. Prevalência da infecção por HIV em parturientes de maternidades vinculadas ao SUS. Rev. Bras. Ginecol. Obstet., v.27, n.1, p.32-36, 2005.

LIGNANI JÚNIOR, L., GRECO, D.B., CARNEIRO, M. Avaliação da aderência aos anti-retrovirais em pacientes com infecção pelo HIV/Aids. Rev. Saúde Públ., v.35, n.6, p.495-501, 2001.

LYRA JÚNIOR, D.P., AMARAL, R.T., ABRIATA, J.P., PELÁ, I.R. A satisfação como resultado de um programa de atenção farmacêutica para pacientes idosos em Ribeirão Preto (SP) - Brasil. Seguim. Farmacoter., v.3, n.1, p.30-42, 2004.

MENEZES DE PÁDUA, C.A., CÉSAR, C.C., BONOLO, P.F., ACURCIO, F.A., GUIMARÃES M.D.C. High incidence of adverse reactions to initial antiretroviral therapy in Brasil. Braz. J. Med. Biol. Res., v.39, n.4, p.495-505, 2006.
MOURA, E.L., PRAÇA, N.S. Transmissão vertical do HIV: expectativas e ações da gestante soropositiva. Rev. Latinam. Enferm., v.14, n.3, p.405-413, 2006.

ORTIGÃO, M.B. AIDS em crianças: considerações sobre a transmissão vertical. Cad. Saúde Publ., v.11, n.1, p.142$148,1995$.

PLUCIENNIK, A.M.A. Prevenção da transmissão vertical materno-infantil do HIV: é mais caro identificar do que tratar a gestante soropositiva. Rev. Assoc. Med. Bras, v.49, n.1, p.12, 2003.

ROMANELLI, R.M.C., KAKEHASI, F.M., TAVARES, M.C.T., MELO, V.H., GOULART, L.H.F., AGUIAR, R.A.L.P., PINTO, J.A. Perfil das gestantes infectadas pelo HIV atendidas em pré-natal de alto risco de referência de Belo Horizonte. Rev. Bras. Saúde Matern. Infant., v.6, n.3, p.329-334, 2006.

SBALQUEIRO, R.L., REGGIANE, C., TRISTÃO, E.D., URBANETZ, A.A., ANDRADE, R.P., NASCIMENTO, D.J., CARVALHO, N.S. Estudo da prevalência e variáveis epidemiológicas da infecção pelo HIV em gestantes atendidas na maternidade do Hospital de Clínicas de Curitiba. DST J. Bras. Doenças Sex. Transm., v.16, n.2, p.40-47, 2004.

SECRETARIA MUNICIPAL DE FORTALEZA. Redução da transmissão vertical do HIV/AIDS Available at: < http:// www.sms.fortaleza.ce.gov.br/internet/noticias_detalhe. asp? varCdNoticia=143>. Accessed on: 15 sep. 2007.

SILVA, N.E.K.; ALVARENGA, A.T.; AYRES, J.R.C.M. AIDS e gravidez: os sentidos do risco e o desafio do cuidado. Rev. Saúde Públ., v.40, n.3, p.474-481, 2006.

STORPIRTIS, S., RIBEIRO, E., MARCOLONGO, R.. Novas diretrizes para assistência farmacêutica hospitalar: Atenção farmacêutica/Farmácia clínica. In: GOMES, M.J.V.M., REIS, A.M.M. Ciências Farmacêuticas: uma abordagem em farmácia hospitalar. São Paulo: Atheneu, 2000. p.521533.

YOSHIMOTO, C.E., DINIZ, E.M.A., VAZ, F.A.C. Evolução clínica e laboratorial de recém-nascidos de mães HIV positivas. Rev. Assoc. Med. Bras., v.51, n.2, p.100-105, 2005.

Received for publication on $26^{\text {th }}$ March 2008 Accepted for publication on $11^{\text {th }}$ May 2009 